\title{
20 RISK FOR INCREASED METAL LEAKAGE DUE TO AGEING OF LANDFILLS?
}

Anna Mårtensson

Department of Soil Sciences, P O Box 7014, Swedish University of Agricultural Sciences, SE-750 07 Uppsala, Sweden

Monica Östman

Department of Soil Sciences, P O Box 7014, Swedish University of Agricultural Sciences, SE-750 07 Uppsala, Sweden

Cecilia Våg

Department of Chemical Engineering and Technology, Chemical Engineering Royal Institute of Technology, SE-100 44 Stockholm, Sweden

Olle Wahlberg

Department of Inorganic Chemistry, Chemical Engineering Royal Institute of Technology, SE-100 44 Stockholm, Sweden

Staffan Agren

The Ragnar Sellberg Foundation for Waste Research and Development, Högbytorp, SE-19793 Bro, Sweden

\begin{abstract}
As landfill ages, oxygen will start to penetrate. We investigated whether aeration of a landfill affected metal leaching. We found that aeration increased cation exchange capacity, but decreased the buffering capacity and the metal-binding capacity. Leachates from an aerated landfill contained less than half the amount of aluminium and iron and more than double the amount of calcium, sulphur and zinc than leachates derived from an identical, but anaerobic, landfill. The leachate from the aerated landfill was capable of extracting metals from the original landfill when recirculated. Leachate from the original landfill treated with leachate from the aerated landfill contained more than twice as much cadmium, copper, iron, sulphur and zinc than leachate from the identical anerobic landfill. We conclude that precautions should be taken considering the fate of deposited metals when extrapolating results derived from studies on landfills at earlier degradation stages to landfills in more progressed phases.
\end{abstract}

\section{KEYWORDS}

Humic substances, Organic wastes, Risk assessment

\section{INTRODUCTION}

The impact of ageing on long-term environmental hazard potential of landfills is not very well known. Currently, little of the deposited metals and other potentially hazardous substances of 
a landfill is considered to be leached during the first decades after disposal (1). This 'no leakage' concept is also supported by (2) extrapolating an observed exponential decline of leaching from landfills in their first degradation phases to very long periods. Thus, the leaching of metals in landfills has been considered to be of minor importance. However, care must be taken when extrapolating results achieved from the first degradation phase of the landfill to a subsequent phase, as settlement processes continue for a very long period up to the next ice age, considered to occur after 10000 years. As the landfill ages anaeobic conditions dominate, the $\mathrm{pH}$ is above neutral and the sulphur is present as metal sulphides. Under such circumstances, deposited metals may be present as minerals, sorbed on minerals, included in amorphous phases and/or bound to complexing sites of the organic matter. The complexing capacity of the disposed and partly anaerobically degraded organic matter, the fraction of the sites available to the heavy metals and the fraction occupied by other metal ions such as calcium and ferrous ions and the amount of humics formed are not yet known. With increasing maturity of the landfill, oxygen will begin to penetrate by gas diffusion and by oxygenated acid rainwater developing aerobic niches. This initiated oxidation will produce carbon dixoide, which will further decrease the $\mathrm{pH}$. In addition, the organic matter and metal sulphides present will degrade and/or oxidize and release bound metals. The metals could then dissolve in the oxidizing pore waters and escape from the landfill with the water flowing through it and also by diffusion. However, altering the conditions of the anaerobically transformed deposited organic matter during the preceding phases may also result in a higher oxidation level of the material, resulting in a higher binding capacity of both toxic metals and other competing metals which are thus retained. To investigate whether ageing processes of a landfill affect the fate of deposited metals, we have initiated a survey where the ageing process has been simulated by aeration.

\section{MATERIALS AND METHODS}

\section{The Högbytorp landfill}

Landfill material was derived from Högbytorp, an industrial landfill in Central Sweden. The present status of the landfill and a material balance is presented by (3). Bore cores from the landfill were drilled out at $10 \mathrm{~m}$ depth, transferred to containers and kept frozen $\left(-20^{\circ} \mathrm{C}\right)$ prior to use. Before starting the experiment the frozen material was chopped and sieved $(5 \mathrm{~mm})$ in a cold-room $\left(-20^{\circ} \mathrm{C}\right)$ in order to minimize the initiation of biological activities in the samples. $\mathrm{pH}$, cation exchange capacity, carbon and nitrogen contents as well as contents of various metals were determined using standard laboratory methods. Chemical and physical characteristics are presented in Table 1. 
Table 1. Status of the initial landfill and peat bog material

\begin{tabular}{|c|c|c|}
\hline & Landfill & Peat bog \\
\hline$\overline{\mathrm{pH}}$ & 8.8 & 5.6 \\
\hline CEC (meq $100 \mathrm{~g}^{-1}$ ) & 57 & 225 \\
\hline Total N ( $\left.\mathrm{g} \mathrm{kg}^{-1}\right)$ & 3 & 27 \\
\hline Total C $\left(\mathrm{g} \mathrm{kg}^{-1}\right)$ & 140 & 360 \\
\hline Organic $\mathrm{C}\left(\mathrm{g} \mathrm{kg}^{-1}\right)$ & 127 & 338 \\
\hline Lignin $\left(\mathrm{g} \mathrm{kg}^{-1}\right)$ & 24 & 65 \\
\hline Hemicellulose $\left(\mathrm{g} \mathrm{kg}^{-1}\right)$ & 45 & 160 \\
\hline Cellulose $\left(\mathrm{g} \mathrm{kg}^{-1}\right)$ & 69 & 111 \\
\hline $\mathrm{Ca}\left(\mathrm{g} \mathrm{kg}^{-1}\right)$ & 25 & 30 \\
\hline $\mathrm{Fe}\left(\mathrm{g} \mathrm{kg}^{-1}\right)$ & 28 & 15 \\
\hline $\mathrm{Mg}\left(\mathrm{g} \mathrm{kg}^{-1}\right)$ & 5 & 3 \\
\hline $\mathrm{S}\left(\mathrm{g} \mathrm{kg}^{-1}\right)$ & 3 & 7 \\
\hline $\mathrm{Zn}\left(\mathrm{g} \mathrm{kg}^{-1}\right)$ & 3 & 0 \\
\hline $\mathrm{Cd}\left(\mathrm{mg} \mathrm{kg}{ }^{-1}\right)$ & 10 & 0 \\
\hline $\mathrm{Cu}\left(\mathrm{mg} \mathrm{kg}{ }^{-1}\right)$ & 179 & 30 \\
\hline
\end{tabular}

Mean values of three replicate determinations

\section{The effect of aeration on the fate of toxic metals}

At the start of the experiment, $700 \mathrm{~g}$ wet weight sieved land fill material was placed in glass cylinders. In the centre of the cylinders tubings were attached to supply inlet and outlet gas to the system. The inlet gas consisted of either air or nitrogen. The outlet gas was led through $\mathrm{NaOH}$ to capture carbon dioxide, followed by another gas wash bottle containing sulphuric acid to capture ammonium. Gas flow rate was set to $5 \mathrm{ml}$ per min. The solutions in the gas wash bottles were titrated at intervals and amounts of carbon dioxide and ammonium produced was calculated. Twice weekly, methane and oxygene concentrations were determined. To detect any occurrence of increased metabolic activity shown as a temperature rise, thermometers were installed in the glass cylinders. Treatments included landfill material exposed to technical gas containing $20.4 \%$ oxygen, with landfill material exposed to nitrogen as the control, natural peat bog material exposed to technical gas containing $20.4 \%$ oxygen and peat bog material exposed to nitrogen. The experiment was stopped after three months, after which the material was characterized with respect to $\mathrm{pH}$, cation exchange capacity, carbon and nitrogen status as described above (Table 2). The remaining material was divided into subsamples and stored frozen.

\section{Effect of aeration on leachates}

Leachates of aerated and anaerobic landfill material were produced by adding respectively $100 \mathrm{ml}$ distilled water to $54 \mathrm{~g}$ wet landfill matter and rotate this for $90 \mathrm{~min}$, followed by centrifugation, repeatedly centrifuging the supernatant followed by filtration. Metal 
concentrations were determined (Table 3). Analysis for presence and separation of water soluble short-chain organic acids was made by high pressure liquid chromatography.

Table 2. Effect of $p H, C E C, C$ and $N$ status by aeration of the landfill and peat bog materials

\begin{tabular}{lllll}
\hline & $\begin{array}{l}\text { Aerated Anaerobic } \\
\text { landfill }\end{array}$ & $\begin{array}{l}\text { Aerated } \\
\text { peat bog }\end{array}$ & $\begin{array}{l}\text { Anaerobic } \\
\text { peat bog }\end{array}$ \\
\hline pH & 7.9 & 8.4 & 5.4 & 5.9 \\
$\mathrm{CEC}\left(\mathrm{meq} 100 \mathrm{~g}^{-1}\right)$ & 69 & 63 & 193 & 182 \\
Total $\mathrm{N}\left(\mathrm{g} \mathrm{kg}^{-1}\right)$ & 4 & 4 & 26 & 26 \\
Total C $\left(\mathrm{g} \mathrm{kg}^{-1}\right)$ & 136 & 135 & 337 & 342 \\
Lignin $\left(\mathrm{g} \mathrm{kg}^{-1}\right)$ & 30 & 22 & 75 & 64 \\
Hemicellulose $\left(\mathrm{g} \mathrm{kg}^{-1}\right)$ & 41 & 40 & 158 & 149 \\
Cellulose $\left(\mathrm{g} \mathrm{kg}^{-1}\right)$ & 60 & 65 & 111 & 98 \\
Carbon dioxide evolution $\left(\mathrm{g} \mathrm{kg}^{-1}\right)$ & 11.3 & 1.3 & 7.3 & 2.0 \\
& & & & \\
\hline
\end{tabular}

Table 3. Quality of leachate from aerated and anaerobic landfill and peat bog

\begin{tabular}{lllll}
\hline & $\begin{array}{l}\text { Aerated } \\
\text { landfill }\end{array}$ & $\begin{array}{l}\text { Anaerobic } \\
\text { landfill }\end{array}$ & $\begin{array}{l}\text { Aerated } \\
\text { peat bog }\end{array}$ & $\begin{array}{l}\text { Anaerobic } \\
\text { peat bog }\end{array}$ \\
\hline $\mathrm{pH}$ & 8.2 & 8.5 & 5.5 & 5.6 \\
$\mathrm{Ca}\left(\mathrm{g} \mathrm{kg}^{-1}\right)$ & 0.6 & 0.1 & 1.7 & 1.0 \\
$\mathrm{~S}\left(\mathrm{~g} \mathrm{~kg}^{-1}\right)$ & 1.3 & 0.0 & 0.4 & 0.4 \\
$\mathrm{Cu}\left(\mathrm{mg} \mathrm{kg}^{-1}\right)$ & 0.7 & 0.0 & 0.0 & 0.0 \\
$\mathrm{Fe}\left(\mathrm{mg} \mathrm{kg}^{-1}\right)$ & 1.4 & 5.0 & 2.8 & 2.1 \\
$\mathrm{Zn}\left(\mathrm{mg} \mathrm{kg}^{-1}\right)$ & 1.1 & 0.0 & 0.2 & 0.1 \\
$\mathrm{Cd}\left(\mu \mathrm{g} \mathrm{kg}^{-1}\right)$ & 1 & 0 & 0 & 0 \\
\hline
\end{tabular}

\section{Metal-binding capacity of the leachates}

The metal-binding capacity of the leachates prepared above was investigated by adding 20 $\mathrm{ml}$ of the leachate from aerated and anaerobic landfills and peat bog respectively to $8.6 \mathrm{~g}$ wet weight of the original untreated landfill. Again, the samples were kept on the roller table and centrifuged and filtered and analysed for presence of metals as before (Table 4). 


\section{Metal-holding capacity of the aerated landfill material}

The metal-holding capacity of the aerated and anaerobic landfill prepared above was investigated by adding $16 \mathrm{ml}$ of $\mathrm{Na}_{2}$-EDTA to $8 \mathrm{~g}$ wet weight material taken from the above prepared aerated and anaerobic landfills and peat bog to achieve final concentrations of 0,2 $10^{-5} \mathrm{M}, 4 \cdot 10^{-5} \mathrm{M}, 6 \cdot 10^{-5} \mathrm{M}$ and $8 \cdot 10^{-5} \mathrm{M}$. Again, the samples were kept on the roller table and centrifuged and filtered as before. Metals were determined as before.

\section{Buffering capacity of the aerated landfill material}

The buffering capacity of the aerated and anaerobic landfill prepared above was then investigated by adding $16 \mathrm{ml}$ of $\mathrm{HCl}$ to $8 \mathrm{~g}$ wet weight material ( $3.7 \mathrm{~g}$ dry weight) taken from the above prepared aerated and anaerobic landfills and peat bog to achieve final concentrations of $\Theta, 8 \cdot 10^{-4} \mathrm{M}, 8 \cdot 10^{-3} \mathrm{M}, 4 \cdot 10^{-2} \mathrm{M}, 8 \cdot 10^{-2} \mathrm{M}, 1.4 \cdot 10^{-1} \mathrm{M}$ and $2 \cdot 10^{-1} \mathrm{M}$. Again, the samples were kept on the roller table and centrifuged and filtered as before. Metals and $\mathrm{pH}$ were determined as before.

Table 4. Metal-binding capacity of the leachates from landfill or peat bog of aerated and anaerobic origin when applied to the original landfill material. Figures shown have been corrected for the initial metal concentrations of the respective leachate

\begin{tabular}{lllll}
\hline Leachate, origin & & & \\
\hline $\begin{array}{l}\text { Aerated } \\
\text { landfill }\end{array}$ & $\begin{array}{l}\text { Anaerobic } \\
\text { landfill }\end{array}$ & $\begin{array}{l}\text { Aerated } \\
\text { peat bog }\end{array}$ & $\begin{array}{l}\text { Anaerobic } \\
\text { peat bog }\end{array}$ & \\
\hline $\mathrm{Ca}\left(\mathrm{g} \mathrm{kg}^{-1}\right)$ & 3.7 & 4.8 & 4.0 & 4.8 \\
$\mathrm{~S}\left(\mathrm{~g} \mathrm{~kg}^{-1}\right)$ & 4.0 & 0.9 & 3.1 & 3.4 \\
$\mathrm{Cu}\left(\mathrm{mg} \mathrm{kg}^{-1}\right)$ & 0.7 & 0.2 & 0.7 & 0.2 \\
$\mathrm{Fe}\left(\mathrm{mg} \mathrm{kg}^{-1}\right)$ & 0.1 & -3.9 & 0.8 & 0.9 \\
$\mathrm{Zn}\left(\mathrm{mg} \mathrm{kg}^{-1}\right)$ & 3.5 & 0.2 & 2.5 & 2.4 \\
$\mathrm{Cd}(\mu \mathrm{g} \mathrm{kg}$ & & & 2.8 & 2.0 \\
\hline
\end{tabular}

\section{RESULTS}

\section{The Högbytorp landfill}

In Table 1, chemical and physical characters of the initial landfill and peat bog material are presented. The landfill had a higher $\mathrm{pH}$, a lower cation exchange capacity and contained less nitrogen and carbon then the peat bog. The landfill had approximately equal concentrations of aluminium and calcium to the peat bog. Concentrations of some metals such as cadmium, copper, lead and zinc were more than twice as high in the landfill than in the peat bog. The peat bog had higher concentrations of sulphur compared to the landfill.

\section{The effect of aeration on the fate of toxic metals}


At the end of the aeration treatment, each gram of aerated land fill and peat bog material had been exposed to $300 \mathrm{ml}$ of oxygen. No methane was detected from either the landfill or the peat bog material as shown from analyses of the outlet gas. Oxygen concentrations of the outlet gas are presented in Figure 1. Carbon dioxide production of the respective treatments is shown in Figure 2 and Table 2. As shown, the carbon dioxide production of the aerated materials was elevated, being 7.5 times higher in the aerated landfill compared to the anaerobic landfill and 3.5 times higher in the aerated peat bog compared to the anaerobic peat bog. No ammonium production occurred. No temperature changes in the material occurred. Aeration of the material resulted in a $\mathrm{pH}$ decrease of both the landfill and the peat bog material and a tendency toward an increased CEC (Table 2). The lignin : hemicellulose : cellulose ratio of the materials were $1.0: 2.3: 2.7$ (aerated landfill), 1.0 : $2.4: 3.9$ (anaerobic landfill), $1.0: 2.1: 1.5$ (aerated peat bog) and $1.0: 2.3: 1.5$ (anaerobic peat bog). This indicated a decrease in more easily available $\mathrm{C}$ as cellulose in the aerated landfill.

\section{Effect of aeration on leachates}

Leachates derived from the aerated and anaerobic materials differed in respect to their content of metals (Table 3). As shown, levels of concentrations of cadmium, calcium, sulphur and zinc more than doubled in leachates from the aerated landfill. Leachate derived from the aerobic landfill was found to contain acetic acid, $0.12 \mathrm{~g}$ $\mathrm{g}$ dry matter of landfill material ${ }^{-1}$, which was not found in the leachate from the anaerobic landfill.

\section{Metal-binding capacity of the leachates}

The metal-binding capacity of leachates derived from the aerated and anaerobic landfill and peat bog showed that lechate from the aerated landfill contained more than twice as much cadmium, copper, iron, sulphur, and zinc than leachate from the anerobic landfills. No elevated concentrations of any metals were observed in the anaerobically treated landfill and peat bog respectively (Table 4).

\section{Metal-binding capacity of the aerated landfill material}

By making regression analyses of the metal concentrations and EDTA concentrations it was found that with increasing EDTA concentrations cadmium $\left(r^{2}=0.98\right)$, lead $\left(r^{2}=0.98\right)$ and zinc $\left(r^{2}=0.98\right)$ increased in leachates of the aerated landfill. No relationships between EDTA concentrations and metal concentrations of leachates from the anaerobic landfill material were observed.

\section{Buffering capacity of the aerated landfill material}

The buffering capacity of the aerated and anaerobic landfill material is presented in Fig. 3. As shown, the aerated landfill material had a lower buffering capacity. By regression analyses of the relationships between metal concentrations and $\mathrm{HCl}$ concentrations it was found that with increasing $\mathrm{HCl}$ concentrations cadmium $\left(r^{2}=0.95\right)$, calcium $\left(r^{2}=0.98\right)$ and zinc $\left(r^{2}=0.92\right)$ increased in the aerated landfill.

\section{DISCUSSION}


For conclusions drawn, it could be of interest to extrapolate the experimentally conducted 'ageing effect'. By comparing the amount of organic carbon initially present ( $127 \mathrm{~g}$ organic $\mathrm{C}$ per $\mathrm{kg}$ landfill material with a volume of $1.65 \cdot 10^{-3} \mathrm{~m}^{3}$ ) with figures presented by (4), the landfill organic matter would be exhausted after $>345$ years given conditions favouring oxygen diffusion. This estimation differs from our experimental data where $0.93 \mathrm{~g}$ of $\mathrm{C}$ were released from the landfill during 82 days, which could be extrapolated to give a complete exhaustion of the organic material after 4 years at a disposal rate of $4 \mathrm{~g} \mathrm{C}$ each year. However, in our experiment, oxygen is less limited than under natural conditions. Thus, we extrapolated the achieved ageing of the aerated landfill in our study to be $345 / 4$ years $=86$ years. When oxidizing the partially anaerobically degraded organic matter of the landfill and the peat bog we observed that the oxidation of the deposited organic material resulted in a production of water-soluble organic acids. These acids have chelating properties which explains the increased mobility of metals in the aerated landfill and the capacity of the aerated landfill leachate to extract metals. We suggest that the lowering of $\mathrm{pH}$ of both the aerated landfill and the peat bog material is a result of an initiated carbon dioxide production. As $\mathrm{pH}$ drops, an increased solubility of metals in anaerobically converted organic material will occur when the material is exposed to oxygen. The observed reduction in $\mathrm{pH}$ could be explained by the formation of short-chained organic acids in the aerated landfill. On the other hand, a tendency towards an increased cation exchange capacity of the aerated landfill and peat bog was also indicated which counteract with the lowered $\mathrm{pH}$ with respect to leaching potential of metals (Table 2). Results, however, point out that an increased mobilization of some metals, including cadmium, lead and zinc, could be foreseen when oxygen enters anaerobically degraded organic material. The initiated oxidation of the partially anaerobically degraded organic matter altered the buffering capacity. An increased mobility of cadmium, calcium and zinc was observed in the aerated landfill. The reasons for the reduced buffering capacity the aerated landfill may be due to the carbon dioxide production as mentioned. However, it may also be due to oxidation of metal sulphides resulting in a production of sulphate ions which further decreases the $\mathrm{pH}$ and increases the amount of free metal ions. The metal-binding capacity of leachates derived from the aerated and anaerobic landfill and peat bog showed that the aerated leachate from the landfill was able to mobilize metals from the treated original landfill material. Leachate from the original landfill treated with leachate from the aerated landfill contained more than twice as much cadmium, copper, iron, sulphur, and zinc as leachate from the anaerobic landfill. When the original landfill material was exposed to leachate from the aerated peat bog, twice as much cadmium and iron was obtained as in the leachate from the anaerobic peat bog. Our observations indicate that aeration of partially anaerobically converted organic materials results in production of chelating agents which will enhance the mobility of metals. It could thus be argued that organic material should not be landfilled since it will increase mobility of metals on a longterm perspective based on our results. However, this conclusion needs to be qualified since it is not only the observed chelating effects which are important characteristics of the organic material in the landfill. The organic material may also substantially decrease the mobility of metals within the landfill by complexation and sorbtion.

\section{CONCLUSIONS}


Metal mobility within landfills which are in a humic phase will increase when oxygen is introduced. Metals will become more mobile and the $\mathrm{pH}$ buffering capacity will be reduced. Recirculating leachates will accentuate the potential for an increased metal mobility within and from the landfill when oxidized conditions are introduced.

\section{REFERENCES}

1. Christensen, J.B., Kjeldsen, P., Albrechtsen, H.-J., Heron, G., Nielsen, P.H., Bjerg, P.P., Holm, P.E. (1994). Attenuation of landfill leachate pollutants in aquifers. Critical Reviews in Environmental Science and Technoloy 24, 119-202.

2. Belevi, H., Baccini, P. (1989). Long-term behaviour of municipal solid waste landfills. Waste Management and Research 7, 43-56.

3. Aulin, C., Neretnieks, I. (1995). Material balance for an industrial landfill. In Proceedings Sardinia 95. Fifth International Landfill Symposium, S. Margherita di Pula, Cagliari, Italy, Oct. 2-6 1995, 3. Cagliari, Italy: CISA Environmental Sanitary Engineering Centre, pp 173-180.

4. Bozkurt, S., Aulin, C., Moreno, L., Netertnieks, I. (1997). Long term release of otxic metals from waste deposits. In Proceedings Sardinia 97. Sixth International Landfill Symposium, S. Margherita di Pula, Cagliari, Italy, Oct. 13-17 1997, 1. Cagliari, Italy: CISA Environmental Sanitary Engineering Centre, pp. 257-278. 